\title{
$O$ século XX e a tragédia do homem comum
}

\section{The Twentieth Century and the tragedy of commom man}

\author{
Adriano de Paula Rabelo* \\ iD https:// orcid.org/0000-0002-2747-6186
}

Recebido em: 14/10/2018

Aceito para publicação em: 16/11/2018

RESUMO: No decorrer do século XX, houve um grande debate em torno da tragédia e da possibilidade de sua recriação num tempo tão distante do século $\mathrm{V}$ a.C., quando ocorreu seu surgimento e seu apogeu e quando Ésquilo, Sófocles e Eurípides, os três grandes tragediógrafos da Grécia, produziram seus trabalhos. Pensadores originários de diversos campos das humanidades tomaram parte nessas discussões. Este artigo sintetiza suas ideias, mostrando como a estatura do ser humano, sua condição social e sua linguagem foram se rebaixando até o século em que autores como Eugene O’Neill, Arthur Miller e Nelson Rodrigues recriaram a tragédia em feição moderna: uma tragédia do homem comum.

Palavras-chave: Tragédia. Trágico. Modernidade. Rebaixamento

ABSTRACT: Along the twentieth century, a long-lasting debate on tragedy and the possibility of its recreation in a time so distant from the fifth century B.C. - when tragedy arose and got to its acme, and also when Aeschylus, Sophocles and Euripides, the three great tragedians of Greece, produced their works - took place. Thinkers from several fields of the humanities took part in these discussions. This article sums up their ideas and shows up how the human being stature, social position and language were getting lower and lower. As a result, throughout the twentieth century, dramatists such as Eugene O'Neill, Arthur Miller and Nelson Rodrigues recreated tragedy in a modern fashion: a common man tragedy.

Keywords: Tragedy. Tragic. Modernity. Lowering

Em seu livro Mimesis, Erich Auerbach mostra como se processou, na literatura ocidental, a dissolução da doutrina clássica dos níveis de representação literária e como se deu a incorporação de uma representação mais séria da realidade cotidiana por parte do romance, aquele que veio a se tornar, após o Renascimento, o gênero narrativo por excelência. Nesse processo, cada vez mais as camadas humanas desprivilegiadas econômica, social e politicamente foram se tornando objeto de representação na literatura. Com isso, houve uma progressiva

* Professor na Faculdade de Letras da Universidade Federal de Minas Gerais (UFMG). E-mail: aprabelo@hotmail.com. 
diminuição do nível de linguagem, bem como da estatura e da condição do ser humano tal como representado nas narrativas. Assim, a epopeia grega deu vida ao astuto Ulisses de Homero, heroico rei de Ítaca, intrépido chefe militar na guerra de Tróia, autor de proezas sensacionais, protegido pela deusa Atena, falante de uma linguagem nobre, centro do universo, "medida de todas as coisas". Indo além das proposições de Auerbach, que chega até o início do século XX, nota-se claramente que a literatura contemporânea é pródiga em apresentar personagens impotentes diante da máquina do mundo, alienados, cínicos, zombeteiros, asquerosos, medidos por todas as coisas, extremamente solitários, abandonados à própria sorte, vítimas da burocracia, aniquilados, falantes de uma linguagem cotidiana, rebaixada, fragmentada ou mesmo mudos. Os personagens de James Joyce, Franz Kafka e Samuel Beckett, para citar apenas três autores representativos, ilustram muito bem essa tremenda mudança na forma como a literatura ocidental passou a representar o homem. A dramaturgia contemporânea naturalmente reflete essa visão.

As variadas tendências teatrais do século $X X$ decorrem basicamente do Realismo e do Naturalismo, preconizando uma aproximação da realidade exterior, um retrato e uma crítica social, muitas vezes assumindo uma postura didática ou política; e do Simbolismo, propondo um afastamento deliberado dessa mesma realidade, objetivando representar a interioridade do homem, os mistérios universais e a poesia da vida moderna. Muitas vezes, essas visões se misturam, surgindo expressões como "realismo psicológico" e "fantasia apolínea". Mesmo as tendências que buscam se afastar tanto do Realismo e do Naturalismo como do Simbolismo, tomam-nos como referência, para que possam negá-los. A tragédia contemporânea, ora aproximando-se da realidade, ora afastando-se dela, ora simbolizando a realidade, é uma expressão marcante desse movimento.

No século XX, muitos dramaturgos, seja dialogando com a longa tradição do gênero, seja criando peças de enredo inédito, escreveram obras que podem ser classificadas como tragédias. Se estamos longe de poder falar em uma nova grande época trágica, uma vez que, em sua maioria, os dramaturgos fizeram apenas incursões, geralmente controvertidas, pela tragédia, devemos nos deter na abordagem de autores e obras que buscaram a recriação do gênero conforme o contexto contemporâneo.

A presença da tragédia no teatro do século XX foi sempre incômoda, não somente pela influência dos teóricos que negam a possibilidade de sua realização na época contemporânea - afirmando que ela já cumpriu seu ciclo histórico e deixou de existir -, mas também pela oposição cerrada que o chamado teatro épico, em tudo contrastante com as formas teatrais que provocam identificação do espectador, lhe moveu. No entanto, uma considerável dramaturgia de caráter trágico foi produzida nesse período. Por outro lado, o interesse pela tragédia e pelo fenômeno do trágico tem se mostrado inesgotável. A própria realidade do século chamado pelo historiador Eric Hobsbawm de "Era dos extremos" foi bastante marcada por circunstâncias em que a humanidade se viu várias vezes colocada em situações-limite, em estado de tensão e terror, sujeita à violência em escala jamais praticada colocando em risco a existência de nações e povos inteiros. Isso faz com que a permanente gravidade do viver nessa época se aproxime bastante de algo 
que poderia ser classificado como "trágico". Talvez essa realidade sociopolítica e cultural do século ajude a explicar o enorme interesse pela tragédia e o gigantesco volume de estudos históricos, críticos e teóricos sobre o gênero que têm sido lançados ano após ano.

Como se constata na história da literatura, os gêneros surgem, evoluem, misturam-se, dão origem a outros gêneros, desaparecem, renascem. A tragédia, como se vê neste texto, modificou-se bastante no decurso dos séculos, assumindo formas, pontos de vista e ideologias que exprimem o contexto histórico em que foi gerada. Em sua tradição, percebe-se uma unidade na diversidade de suas manifestações. Assim, um dramaturgo como Racine talvez esteja mais próximo de um Eurípides do que este está de um Ésquilo, por exemplo. Do mesmo modo, a hesitação e o não saber agir do moderno Hamlet o aproxima bastante de muitos personagens não só do teatro mas de toda a literatura contemporânea. Pouco praticada durante a antiguidade latina, desaparecida durante a Idade Média e muito em baixa após o advento do drama burguês, a tragédia conheceu um ressurgimento no século XX. Tal movimento teve início em culturas de grande tradição teatral, influenciando consideravelmente o teatro do Ocidente.

Na Alemanha, os dramaturgos expressionistas do início do século, como Georg Kaiser (1878 a 1945), Ernst Toller (1893 a 1939), Paul Kornfeld (1889 a 1942) e Walter Hasenclever (1890 a 1940), inspirados pelo teatro de Strindberg, buscaram a expressão de um espírito marcado pela tragédia, já que a interioridade do ser humano, que eles buscavam representar de um ponto de vista religioso e político, seria algo essencialmente trágico por suas contradições tantas vezes insolúveis. Estética surgida no contexto do pós-Primeira Guerra Mundial, acontecimento que deixou profundas marcas na mentalidade europeia, o expressionismo no teatro revelou certa descrença nos projetos coletivos e se realizou como uma dramaturgia voltada para o eu, para a interioridade do homem, resultando numa rarefação da construção dramática. Com isso, será a perspectiva do protagonista que definirá como são - ou parecem ser - as outras personagens. Isso, obviamente, dá ao drama expressionista uma estrutura própria.

$\mathrm{Na}$ França da primeira metade do século, importantes dramaturgos escreveram obras que recriavam enredos de tragédias gregas, geralmente na forma de alegorias retratando problemas da contemporaneidade.

Jean Cocteau (1889 a 1963) escreveu uma Antígona (1922) e uma recriação da história de Édipo intitulada A máquina infernal (1934), além de ter explorado a mitologia grega na tragédia Orfeu (1927). Influenciado pela estética simbolista, o autor buscou a criação de um teatro em que pintura, mímica, dança, decoração, fala, música, acrobacia, vanguardismo se misturassem, expressando o insólito e criticando a sociedade. $\mathrm{O}$ teatro de Cocteau possui muitos pontos de identificação com o surrealismo, palavra que à época abarcava quase toda manifestação que tentasse afastar-se do realismo e do naturalismo. Com suas recriações de tragédias gregas, o autor - que prezava bastante o chamado sucesso de escândalo - objetivou renovar a tragédia clássica, parafraseando e reinterpretando com grande ousadia algumas das principais obras do teatro antigo. Em A máquina infernal, por exemplo, a esfinge, tendo assumido a forma de uma bela moça, apaixona-se por Édipo e lhe proporciona facilmente os meios para a resolução do célebre enigma que define o 
homem pelo seu modo de locomoção. Além disso, no princípio de cada um dos cinco atos, uma voz gravada resume solene e gravemente a ação no tempo e no espaço, além de enfatizar o caráter inexorável da marcha da tragédia, a despeito das esperanças e das vãs tentativas dos seres humanos para dela escapar.

Outro dramaturgo que fez tentativas de renovação da tragédia clássica foi Jean Giraudoux (1882 a 1944). Autor apaixonado pela Antiguidade, a maioria de suas peças tratam de temas gregos e romanos - Anfitrião 38, Tessa, Os Gracos - ou inspirados no Antigo Testamento - Judite, Cântico dos cânticos, Sodoma e Gomorra. Duas de suas peças recriam, à maneira clássica, temas da tragédia grega: A guerra de Tróia não ocorrerá (1935) e Electra (1937). Seu teatro, bastante literário, ressoa sempre a considerada alta cultura.

Tendo sua vida profundamente marcada pelas duas grandes guerras mundiais do século, Giraudoux escreveu sua primeira tragédia "grega" como peça de atualidade, uma vez que, no momento de seu lançamento, a palavra "guerra" pairava como uma terrível lembrança e uma assustadora ameaça por toda a Europa. Assim, A guerra de Tróia não ocorrerá, retrabalhando os episódios mais conhecidos da Ilíada, surge como uma previsão do conflito entre a França e a Alemanha - que culminará com a Segunda Guerra Mundial - e uma exortação a paz. Questionando se a guerra de Tróia poderia ter sido evitada, o autor faz uma reflexão acerca de todas as guerras, mostrando que todos os seres humanos são responsáveis por suas inter-relações. Portanto, abortar a guerra iminente seria uma questão de fazer com que cada um se livrasse de uma mácula infame, pois a morte de cada ser humano concernirá a todos. Giraudoux dotou seus personagens trágicos dessa liberdade de escolha, retirando-os do mundo da fatalidade e da necessidade no qual Homero e os tragediógrafos gregos os apresentaram.

A Electra faz par com A guerra de Tróia não ocorrerá na medida em que também toma por referência a realidade belicosa da Europa dos anos 30, mais especificamente se relaciona com a guerra civil espanhola. Muitos intérpretes viram no texto de Giraudoux uma expressão do debate ideológico que opôs as nações democráticas, encarnadas em Electra, às nações autoritárias, representadas por Egisto. $O$ trágico da peça difere bastante daqueles expressos pelos tragediógrafos gregos que trataram dos infortúnios da linhagem dos atridas. Em Ésquilo, o foco de interesse está em Orestes, sendo ele o personagem principal da trilogia que leva seu nome. A ação trágica termina com seu julgamento e sua difícil absolvição. Apolo e Atena abrem e fecham uma tragédia que transcorre sob o signo da transcendência. Sófocles desloca o centro de interesse para Electra, que exige uma justiça inexorável, para isso armando e controlando a ação de seu irmão. Eurípides, coerentemente com o espírito crítico da sofística, desdenha da cena de reconhecimento tal como imaginada pelos outros dois grandes tragediógrafos, além de derrubar a tragédia de sua enorme altitude, fazendo com que Electra se case com um lavrador. Conservando o enredo básico do mito grego, mas renovando-o, Giraudoux buscou tematizar assuntos não tocados pela lenda dos atridas. A peça começa com o insólito casamento entre Electra e um jardineiro. $\mathrm{Na}$ cerimônia, fazem-se presentes Orestes e três meninas eumênides, que o autor faz com que cresçam à medida que a ação se desenvolve. Assim, quando o filho de Agamenon tiver matado Clitemnestra, as eumênides já estarão adultas e prontas 
para persegui-lo. Electra só pensa em seu pai morto e em seu irmão exilado. Investiga e deseja saber toda a verdade sobre os acontecimentos obscuros do passado de sua família. Seu percurso será, pois, o da ascensão da ignorância ao conhecimento. Ao final, Electra vinga o assassinato de seu pai, mas perde tudo. Ao final, a justiça almejada por ela se realiza na forma da destruição de todos, culpados ou inocentes. Seria essa a justiça final de todas as guerras.

Autor bastante influenciado por Cocteau e Giraudoux, Jean Anouilh (1910 a 1987) também fez tentativas de recriação de tragédias gregas no século XX. No início dos anos 40, ele já havia retrabalhado o mito orfeônico numa terna fantasia teatral intitulada Eurídice. Orfeu é um violinista de rua que, com sua música, conquista Eurídice, uma atriz de província. Fugindo de seu amante, para que ele não descubra máculas de seu passado, ela encontra a morte, fazendo com que Orfeu também abandone a vida ao recusar os compromissos do cotidiano, a fim de proporcionar a seu amor uma pureza eterna.

Quanto à tragédia especificamente, sua Antígona (1944) apresenta personagens trajados em roupas modernas e falando uma linguagem contemporânea do autor, que em seu teatro comumente fazia uso de termos vulgares e mesmo grosseiros. Anouilh, como se vê, trata com realismo os temas clássicos, buscando a melhor imitação da condição humana tal como ela se expressa em seu tempo, tendo as liberdades tomadas por ele provocado uma reação por parte dos críticos mais conservadores. A peça foi bastante analisada levando em conta o contexto francês da Segunda Guerra Mundial, sendo o personagem Creonte visto como um teórico da colaboração, e Antígona, como um símbolo da resistência à ocupação nazista.

Sua Medeia (1946) segue bem de perto o enredo do mito grego tal como expresso na tragédia de Eurípides, mas emprega também uma linguagem moderna. Outra característica do teatro de Anouilh é a apresentação de questionamentos de natureza filosófica. É o que aparece no desfecho da ação dessa peça. Após a tremenda vingança de Medeia, Jasão faz uma reflexão em que afirma a primazia da vida em relação às forças da morte, o que, como se sabe, poderia ser lido como uma mensagem com evidente referência na realidade da época em que a obra surgiu.

Ainda durante a Segunda Guerra Mundial, o filósofo existencialista Jean-Paul Sartre (1905 a 1980) escreverá As moscas (1943), recriando mais uma vez a tragédia da família de Orestes e Electra. Apresentada durante a ocupação de Paris pelos alemães, a peça desenvolve-se num clima bastante semelhante ao vivido pela França naquele momento. Praticante de um teatro engajado, o autor fez de sua tragédia uma peça de tese em que expunha suas ideias filosóficas e políticas, exortando o povo francês à resistência. O Orestes de Sartre é uma expressão do homem tal como visto pelos existencialistas: um solitário num mundo absurdo, um caráter em processo de construção, tendo de fazer escolhas pelas quais é responsável, pois suas decisões têm consequências morais que comprometem toda a sua vida.

Se esses textos de autores franceses retomam os mitos clássicos, mostrando personagens de elevada estirpe, sua referência no mundo exterior são os problemas da humanidade encarnada no homem comum, que é primeira vítima da 
manipulação política e da violência institucionalizada com a qual todos tiveram de se haver no decurso do século.

Nos Estados Unidos, três de seus maiores dramaturgos acreditarão na possibilidade da tragédia em expressão contemporânea, retratando os problemas contemporâneos e mostrando em cena personagens contemporâneos.

Eugene O’Neill (1888 a 1953), influenciado pelo pensamento de filósofos como Schopenhauer, Kierkegaard e Nietzsche, bem como pela dramaturgia de Strindberg e dos expressionistas alemães, vê a condição humana como essencialmente trágica, já que a angústia decorrente do peso de viver seria a condenação do homem pela consciência de sua situação no universo.

Tennessee Williams (1911 a 1983) propõe que, na atemporalidade do universo dramático, assiste-se à afirmação da dignidade humana através da escolha, por parte dos personagens teatrais, dos valores morais pelos quais decidem pautar sua vida. Isso provoca a piedade no espectador moderno, que encontra grande dificuldade de realizar essa mesma escolha na vida real, já que a desumanização do homem, comum em nosso tempo, faz com que sua sensibilidade e seus sentimentos sejam profundamente reprimidos. Uma tragédia moderna teria a função de re-humanizar o espectador, dando livre curso a suas emoções ao menos no curto período de duração de uma peça teatral.

Dos grandes dramaturgos norte-americanos do século XX, Arthur Miller (1915) é, do ponto de vista teórico, o mais interessante. Defendendo a classificação de sua peça A morte do caixeiro-viajante (1949) como uma tragédia, ele escreveu o pequeno mas instigante artigo "A tragédia e o homem comum", no qual apresenta uma interpretação do gênero trágico como a luta entre um protagonista medíocre mas essencialmente bom e um universo essencialmente mau. Para Miller, o homem comum tem tantas prerrogativas para se tornar personagem de obras trágicas quanto os reis e os príncipes. A psiquiatria moderna, baseando suas análises dos problemas emocionais de pessoas comuns nas histórias de Édipo, Orestes, Electra, por exemplo, o comprovaria. O sentimento do trágico "é evocado em nós quando estamos em presença de um personagem que está pronto para sacrificar a sua vida, se preciso for, para assegurar uma coisa - seu senso de dignidade pessoal" (MILLER in MARTIN \& CENTOLA, 1996, p. 4). Assim, a tragédia decorreria da mais completa compulsão do protagonista em avaliar-se de forma justa, revoltando-se e investindo de forma violenta contra um cosmos aparentemente estável e incompatível com ele. A constatação da imutabilidade das coisas que nos cercam provocaria o terror e o medo tradicionalmente associados à tragédia. $\mathrm{O}$ patético adviria da incapacidade do protagonista para agarrar-se a uma força superior, por causa de sua tolice ou de sua insensibilidade.

Mesmo a falha trágica se manifestaria na vida do homem comum da tragédia contemporânea, não sendo necessariamente uma fraqueza:

A falha ou fissura no personagem realmente não é nada - e não necessita ser nada - além da sua inerente relutância em ficar passivo diante do que ele concebe como um desafio a sua dignidade, à imagem que ele faz da legitimidade de sua condição. Somente os passivos, somente os que aceitam o seu quinhão sem uma represália sequer, são "isentos de falha". Muitos de nós 
O autor critica a visão psiquiátrica da vida, da qual decorrem as interpretações que situam a origem da tragédia na mente do protagonista ou lançam a toda a culpa sobre as mazelas sociais, apresentando um herói praticamente sem falhas. Miller postula um equilíbrio entre culpabilidade e inocência decorrente do medo que o herói trágico sente de ser deslocado da imagem que construiu de si mesmo na luta por uma justificação de sua existência neste mundo e por sua autorrealização.

A peça A morte do caixeiro-viajante é a realização mais bem-acabada das ideias de Arthur Miller sobre a tragédia. Nela, o protagonista Willy Loman não se apresenta como o herói da tragédia à moda clássica. Não se trata de uma pessoa bem-nascida nem sequer de um membro importante de sua comunidade. É um cidadão qualquer, possuindo muitos defeitos, apequenado pela burocracia e pela massificação do nosso tempo. Em realidade, não se pode apontar sua falha trágica como exclusivamente sua. É uma falha de todos que, como ele, são uma encarnação do malogro de suas crenças e expectativas, tragados pela mecânica da sociedade contemporânea. Assim como os reis e os príncipes representavam a nação na tragédia antiga, Willy Loman representa a frustração do sonho do self-made man norte-americano. Desse modo, para a audiência contemporânea, sua queda equivaleria à queda de Édipo para a audiência grega da Antiguidade. $\mathrm{O}$ fracasso de um cidadão como Willy significa o fracasso de toda um modo de estruturação da sociedade, assim como as desgraças de Édipo significam a desgraça de todo o reino de Tebas. Talvez mesmo se poderia dizer que o caso de Willy é mais trágico, pois se um novo rei poderia tomar o poder e restabelecer a ordem no estado antigo, na organização contemporânea não há sucessores capazes de recriar a ordem de coisas estabelecida nem condições que o permitam. Portanto, cada Willy Loman que morre exprime a degradação da forma de sociedade em que vivemos. Se há algum consolo, é a conscientização de Biff, o filho do caixeiro-viajante, depositário do legado de esperanças e sonhos do pai, que no final percebe a tolice e o vazio dessas esperanças e desses sonhos, afirmando que não cometerá os mesmos erros de seu pai.

No decurso do século $X X$, a tragédia continuou sendo um dos temas mais explorados pelos teóricos do teatro. Em certos momentos, em especial no final dos anos 20 e no decurso dos anos 30 e 40, aflorou o debate sobre a possibilidade da escritura de obras trágicas na época contemporânea. Tanto posições afirmativas como negativas foram sustentadas por pensadores que mergulharam na história do gênero.

Teóricos como Walter Benjamin (1892 a 1940), Joseph Wood Krutch (1893 a 1970) e George Steiner (1929) negaram a possibilidade da expressão trágica no teatro contemporâneo.

Benjamin, em Origem do drama barroco alemão (1928), vê a tragédia antiga como radicalmente diversa do que se chama tragédia moderna, que, segundo ele, surgiu com os dramaturgos barrocos. Benjamin chega ao ponto de classificar as duas manifestações como dois gêneros distintos, designando-os por palavras diversas: tragödie (tragédia nos moldes gregos), obra fundamentada no mito, apresentando 
uma estreita relação entre o destino humano e o cosmos; e trauerspiel (peça triste, drama barroco), que tem seus fundamentos na história, retratando a interioridade do homem moderno. Segundo Benjamin, o conteúdo e o objeto do drama barroco é "mais autêntico, é a própria vida histórica, como aquela época a concebia. Nisso ele se distingue da tragédia, cujo objeto não é a história, mas o mito, e na qual a estatura trágica das dramatis personae não resulta da condição atual, radicada na monarquia absoluta, e sim de uma condição pré-histórica, radicada no heroísmo passado" (BENJAMIN, 1984, p. 86).

Krutch, em artigo intitulado "A falácia trágica" (1929), ataca as tentativas de se escrever tragédias modernas sob o argumento de que, diferentemente do homem antigo, o moderno não possui uma clara consciência de que suas ações neste mundo sejam significativas, tendo isso representado o fim da possibilidade do heroísmo e da grandeza humana. Sendo a tragédia "uma afirmação de fé na vida, uma declaração de que mesmo que não haja Deus no céu, há pelo menos o Homem na terra" (KRUTCH in LEVIN, 1960, p. 166), nosso tempo seria posterior tanto ao fim da glória de Deus quanto ao fim da glória humana. Conforme Krutch,

Se peças e romances de hoje lidam com pessoas de condição inferior e com emoções menos poderosas, não é porque nos tornamos interessados em espíritos ordinários e em suas aventuras sem nenhum fascínio, mas porque chegamos ao ponto de, quer o admitamos ou não, conceber a alma do homem como ordinária, assim como as suas emoções. (KRUTCH in LEVIN, 1960, p. 164)

Para Steiner, os dramaturgos modernos não são capazes de criar uma tragédia verdadeira, porque o sistema de valores e a mitologia que deu origem e sustentou o gênero não mais existe. A mentalidade voltada para a explicação científica do mundo, bem como a ética cristã, o marxismo e o racionalismo possuiriam uma base essencialmente otimista, buscando explicar ou remediar o sofrimento do homem. Isso seria absolutamente incompatível com o universo da necessidade cega retratado pela tragédia, no qual se apresenta um sofrimento que vai muito além da capacidade de explicação e de solução por parte do ser humano:

O teatro trágico nos afirma que as esferas da razão, da ordem e da justiça são terrivelmente limitadas e que nenhum progresso científico ou técnico estenderá seus domínios. Fora e dentro do homem está l'autre, a "alteridade" do mundo. Chame-a como quiser: Deus escondido e maligno, destino cego, tentações infernais ou fúria bestial de nosso sangue animal. Ela nos aguarda emboscada nas encruzilhadas. Zomba de nós e nos destrói. Em alguns poucos casos, nos conduz, após a destruição, a um repouso incompreensível.

Bem sei que nada disso constitui uma definição da tragédia. Mas não há uma bela definição abstrata que nos possa servir. Quando dizemos "teatro trágico" sabemos do que estamos falando; não com toda precisão, mas o bastante para reconhecer claramente uma coisa que é real. (STEINER, 1991, p. 13) 
Importantes teóricos do teatro, por sua vez, defenderam não só a possibilidade como a pertinência da tragédia contemporânea. Entre muitos que trataram do tema, assumindo esse posicionamento, estão Albert Camus (1913 a 1960), John Gassner (1903 a 1967), Elder Olson (1909), Eric Bentley (1916) e Raymond Williams (1921 a 1988).

Camus, em 1955, numa conferência proferida em Atenas, intitulada "Sobre o futuro da tragédia", sustentou que assim como na Grécia do século V a.C. e na Inglaterra elizabetana, estaríamos passando, na época atual, por um momento trágico no qual as noções predominantes de divindade e totalidade estariam em transição para o predomínio do individualismo e do racionalismo, sendo essas duas ordens de coisas irreconciliáveis. Portanto, a ordem do humano estaria em conflito com a do divino. Tal conflito resultaria na afirmação de uma justificativa e de uma significação para a existência, bem como da dignidade do indivíduo. A tragédia, a seu ver, sempre aflorou em momentos assim, quando o ser humano abandona uma forma de civilização estabelecida há tempos sem ter assumido ainda uma nova forma que dê respostas a seus questionamentos vitais. A tragédia desapareceria nas épocas em que os ideais religiosos ou individualistas atingissem a predominância no espírito humano, pois poria fim à ambiguidade e à tensão provocadas pelas exigências universais e individuais em conflito:

Há tragédia no momento em que o homem por orgulho (ou mesmo por estupidez, como Ajax) contesta a ordem divina, personificada em um deus ou encarnada na sociedade. E a tragédia será tanto maior quanto mais essa revolta for legítima e mais essa ordem for necessária.

Em consequência, tudo o que, no interior da tragédia, tende a romper esse equilíbrio destrói a tragédia. Se a ordem divina não pressupõe nenhuma contestação e nada admite além da culpa e do arrependimento, não haverá tragédia.(...) $\mathrm{O}$ drama religioso é possível, mas não a tragédia religiosa.(...)

Inversamente, tudo o que liberta o indivíduo e submete o universo à lei humana, em particular pela negação do mistério da existência, destrói novamente a tragédia. A tragédia ateia e racionalista é também impossível. Se tudo é mistério, não há tragédia. Se tudo é razão, também não. A tragédia nasce entre a sombra e a luz, por oposição. Isso é compreensível. No drama religioso ou ateu, o problema de fato está resolvido previamente. Na tragédia ideal, ao contrário, não há nenhuma resolução. O herói se revolta e nega a ordem que o oprime, o poder divino, que, pela opressão, afirma-se na medida mesma em que é negado. Ou seja, a revolta por si mesma não provoca a tragédia. Nem a afirmação da ordem divina. É necessário uma revolta e uma ordem divina, uma dando sustentação à outra, reforçando a outra com sua própria força.(...)

E se a tragédia acaba em morte ou em punição, é importante perceber que o que se pune não é o crime por si mesmo, mas a obstinação do herói que negou o equilíbrio e a tensão. (CAMUS, 1994, pp. 216-217) 
Gassner vê a definição de tragédia dada por Aristóteles como base para todas as definições do termo ao longo dos séculos, construindo sua própria definição também com base nos efeitos psicológicos da ação trágica. Cada época faria sua própria interpretação do termo, refletindo seu contexto cultural e suas estruturas de pensamento. Assim, contemporaneamente nossa visão da tragédia está afetada pelas descobertas das ciências que lidam com a psique humana, mas também pelo senso comum. Diante da tragédia, o espectador atual purgaria algumas complicações interiores que o incomodam, comovendo-se com as paixões representadas mas presentes no inconsciente de cada um de nós. Com o distanciamento de sua encenação no palco, é possível analisá-las e julgá-las, isto é, compreendê-las. Assim, o espectador alcançaria um "esclarecimento trágico". Portanto, à clássica definição de catarse como a purgação das paixões decorrentes da piedade e do medo, Gassner adiciona o esclarecimento, a compreensão:

Para os fins da tragédia, "piedade e medo", conforme minha visão, são ineficazes a não ser que formem uma tríade com o esclarecimento, e a não ser que esse casamento entre a emoção e a compreensão nos eleve acima dos perturbadores acontecimentos de uma peça. O neurótico é curado somente quando é retirado do mundo de pesadelo de seus conflitos interiores pelo reconhecimento e pelo entendimento de sua natureza e de sua origem. O pecador é redimido somente após compreender a verdadeira natureza de sua situação. A experiência neurótica e a do pecador encontram paralelo na experiência da catarse. (GASSNER, 1960, p. 65)

Gassner vê a realização desses pressupostos para a tragédia em obras de dramaturgos como Heinrich von Kleist, Georg Büchner, Henrik Ibsen, August Strindberg, George Bernard Shaw, Federico García Lorca, Clifford Odets, Eugene O'Neill, Jean-Paul Sartre e Arthur Miller.

Para Olson, a tragédia, mais que a imitação de personagens de estirpe superior, é a imitação de caracteres superiores. Tais caracteres independem da condição social ou do poder político do personagem. A constatação de que as tragédias do passado ainda comovem o espectador de hoje atesta a atualidade do gênero. A crise da tragédia no nosso tempo decorreria não da impossibilidade de sua realização na atualidade, mas da escassez de autores verdadeiramente vocacionados para escrevê-la:

A tragédia é possível na época atual?

Uma crença muito difundida é a de que não é, pois os reis e os nobres perderam sua aura de dignidade. Isso me parece uma enorme banalidade. É perfeitamente possível fazer com que uma pessoa comum, de baixa extração social, seja uma figura trágica; assim como é possível encher o palco de reis e nobres e não haver tragédia alguma. Não existe um assunto naturalmente afeito à tragédia ou à comédia. O que importa é o modo como o tema é 
desenvolvido, a concepção dramática e o tipo de arte que é praticado para realizá-la.(...)

Também se diz com frequência que a tragédia e as formas similares se tornaram impossíveis em nosso tempo, porque perdemos nosso senso de modelos ou nos tornamos tão cínicos que já não acreditamos na elevação moral, ou tão divididos em nossas crenças que o que é trágico para uns é cômico para outros. Tais noções têm ecoado aqui e ali nas últimas décadas. Algo deve ser dito em primeiro lugar: provem-no. Facilmente poder-se-ia contra-argumentar de forma mais elaborada, mas acredito que isso é desnecessário. $\mathrm{O}$ simples fato de que as grandes tragédias do passado continuam a exercer um efeito poderoso sobre nós já é suficiente para refutar todas essas hipóteses, uma vez que, se elas fossem verdadeiras, esses efeitos seriam impossíveis.

Realmente não vejo nenhuma razão para que não haja tragédia em nosso tempo, exceto pelo fato de ela ter caído em mãos de poetas que não são dramaturgos, caindo em descrédito, enquanto os verdadeiros dramaturgos rejeitaram o que tais poetas andaram fazendo e foram atraídos pelas possibilidades do teatro realista em prosa. (...)

Não proponho que todos os dramaturgos abandonem o que estão fazendo para se empenhar na escritura de tragédias. Só desejaria que aqueles que têm uma verdadeira vocação para a tragédia percebam que não há nenhuma razão para que não a empreguem. Não estou sugerindo que eles deveriam tomar por modelos as grandes tragédias do passado, mas que deveriam buscar descobrir o que poderá ser grande tragédia no futuro. Não estou sugerindo tampouco que o drama sério volte-se para o passado, mas que ele se liberte do passado imediato. Longe de reivindicar um novo conservantismo, proponho uma nova revolução; uma extensão, não uma contração, das artes dramáticas. (OLSON, 1961, pp. 255257)

Para Bentley, a tragédia moderna deve se realizar como uma ampla e profunda representação da vida do protagonista, na qual o problema trágico seja sério e procedente, e a capacidade humana de enfrentá-lo seja real, pois o gênero trágico representa a afirmação da força espiritual do herói. Tragédia seria, portanto, sofrimento e resistência. A postura do dramaturgo trágico deve ser equilibrada, evitando os excessos tanto de otimismo quanto de pessimismo, pois um e outro comprometeria a causalidade e as consequências trágicas:

Eu estaria inclinado a afirmar que toda tragédia é uma porção larga e profunda da vida de um indivíduo e, pelo menos por dedução, de seus semelhantes, na qual, nem os problemas do homem nem sua habilidade em lidar com eles, são diminuídos. A tragédia não pode ser de um otimismo extremo, pois isto seria subestimar o problema; não pode ser de um pessimismo extremo, pois isto significaria perder a fé do homem. No coração da tragédia está uma luta dialética violenta, na qual a vitória de qualquer das partes é crível. Que a ruína do herói seja "inevitável" 
em vários tipos de tragédia é uma ironia, pois esse mesmo herói, que não possui qualquer chance de vencer, no final passa a ser o vencedor espiritual. Os casos de tragédias que, como $E l$ Cid e Fausto, têm um final feliz, fazem-nos lembrar que o gênero não é o oposto da comédia. É uma maneira de olhar as coisas. Na comédia, vemos e criticamos a vida do homem; na tragédia, sentimos e avaliamos seu destino. (BENTLEY, 1991, p. 81)

Raymond Williams considera que cada tipo de tragédia somente pode ser compreendido em seu contexto histórico. A experiência trágica acarreta uma perda irreparável e a sensação de que o protagonista é de algum modo alienado. As condições dessa alienação variariam de época para época. A diversidade da experiência trágica, portanto, deve ser interpretada tomando-se por referência as convenções e as instituições em transformação:

A experiência trágica, por causa de sua importância central, normalmente atrai as crenças e tensões fundamentais de um período, e a teoria da tragédia é interessante principalmente nesse sentido, pois através dela as formas e as inclinações de uma cultura particular é frequentemente percebida em profundidade. (...)

A tragédia não é um único e permanente tipo de acontecimento, mas uma série de experiências, convenções e instituições. Não se trata de interpretar esse conjunto de coisas pela referência a uma permanente e imutável natureza humana. Ao contrário, as variedades da experiência trágica devem ser interpretadas pela referência às convenções e instituições em mudança. $\mathrm{O}$ caráter universalista de muitas teorias da tragédia está no polo oposto de nosso interesse. (WILLIAMS, 1966, p. 45)

Segundo Williams, a preocupação com a ordenação do mundo em nosso tempo seria expressa pela tematização das conflagrações sociais, da revolução e da guerra. A tragédia moderna refletiria, portanto, a preocupação do homem contemporâneo com a desordem social e a violência, as quais provocam grande comoção. A ação da tragédia moderna não retrata o conflito entre o indivíduo e os deuses ou as instituições, mas apresenta-o confrontando outros indivíduos. $\mathrm{O}$ ato revolucionário seria a única ação apropriada contra a desordem do mundo. Porém ele é gerador de nova desordem. Daí resulta um ciclo trágico. A tragédia moderna proporciona uma conscientização da desordem em que vivemos, reafirmando a necessidade de prosseguir lutando. Desse modo, o permanente processo de mudança no modo como as coisas se organizam seria a única forma de impedir a fixação e a conservação da desordem. Como Camus, Williams acredita que as épocas trágicas ocorrem nos momentos de transição de uma ordenação sociocultural para outra:

A tragédia significativa parece não ocorrer em períodos de estabilidade real nem em períodos de conflito aberto e decisivo. A característica mais comum das épocas em que ele ocorre é a 
existência de um período que precede o colapso e a transformação numa determinada cultura. É necessário que haja uma tensão real entre o velho e o novo: entre as crenças recebidas, incorporadas nas instituições e nas respostas à crise, e as novas e vívidas contradições e possibilidades. Se as crenças recebidas já entraram completamente em colapso, esse tipo de tensão obviamente está ausente. (WILLIAMS, 1966, p. 55)

Por fim, apresento uma síntese da teoria da tragédia do prestigioso crítico Northop Frye (1912 a 1991), que dá ênfase ao tema da busca, sendo uma espécie de "jornada noite adentro" ou uma viajem no escuro. Para ele, existem quatro gêneros fundamentais: romance, tragédia, sátira e comédia. Cada um deles constituiria um episódio de um mito de procura e corresponderia a uma estação do ano. A tragédia apresentaria características do outono. Ela é concebida como um contínuo que teria partido da sátira e tenderia para o romance. Tais estações literárias seriam determinadas pela estatura do protagonista, dependendo da forma como o enxergamos, ou seja, favorável ou desfavoravelmente:

$\mathrm{Na}$ estória romanesca as personagens ainda são largamente personagens de sonho; na sátira, tendem a ser caricaturas; na comédia as suas ações se torcem para ajustar-se às exigências de um final feliz. Na tragédia plena, as principais personagens libertam-se do sonho, libertação que é ao mesmo tempo restrição, porque a ordem natural está presente. Por mais densamente que ela possa estar juncada de espectros, presságios, bruxas ou oráculos, sabemos que o herói trágico não pode simplesmente esfregar uma lâmpada e invocar um gênio que o tire do apuro.(...) O herói trágico é muito grande se comparado conosco, mas há algo nele, algo que fica do lado oposto à audiência, comparado com o que ele se mostra pequeno. Esse algo pode ser chamado Deus, deuses, fado, acaso, fortuna, necessidade, circunstância ou qualquer combinação entre eles, mas, seja o que for, o herói trágico fica entre nós e esse algo. (FRYE, 1973, p. 204)

Segundo Frye, a tragédia subdivide-se em seis fases. Na primeira, mais próxima do romance, o protagonista, apesar de sua queda eventual, preservaria a maior dignidade possível em relação aos outros personagens. A segunda seria uma tragédia de juventude do herói, sustentando-se da inexperiência deste. A terceira destacaria o fato de o protagonista ser bem-sucedido em sua busca, o que compensaria a sua queda pessoal. A quarta mostraria a queda do herói como decorrência de sua hybris e de sua falha trágica, marcando o momento em que ele passa da inocência à experiência e à responsabilidade. A quinta retrataria a diminuição da estatura do personagem central diante da imponência das forças exteriores. A sexta trataria do impacto e do horror na vida do herói trágico.

A tragédia representaria um ciclo de morte e renascimento através da redenção e da ressurreição do herói, já que sua destruição, como o fim das estações, leva ao seu posterior ressurgimento: 
Tão logo Adão cai, entra na vida por ele provocada, que é também a ordem da natureza, tal como a conhecemos. A tragédia de Adão, portanto, resolve-se, como todas as outras tragédias, na manifestação da lei natural. Ingressa num mundo no qual a existência é em si mesma trágica, não a existência modificada por um ato, deliberado ou inconsciente. Existir meramente é perturbar o equilíbrio da natureza. Todo homem natural é uma tese hegeliana e implica uma reação: cada novo nascimento provoca a volta de vingadora morte.(...)

Assim como o crítico literário acha Freud mais sugestivo para a teoria da comédia, e Jung para a teoria da história romanesca, assim também para a teoria da tragédia confia-se naturalmente na psicologia da vontade de poder, como exposta por Adler e Nietzsche. Aqui, encontra-se uma vontade "dionisíaca" agressiva, embriagada por sonhos de sua própria onipotência, chocando-se com uma sensação "apolínea" da ordem externa e imutável. Enquanto mimese do ritual, o herói trágico não é realmente morto ou comido, mas o fato correspondente em arte ainda se realiza, uma visão da morte que arrasta os sobreviventes para uma nova unidade. Enquanto imitação do sonho, o inescrutável herói trágico, como o cisne altivo e silencioso, torna-se capaz de falar em artigo de morte, e a audiência, como o poeta em Kubla Khan, revive-lhe o canto dentro de si mesma. Com sua queda, um mundo maior, além, que seu espírito gigantesco bloqueou, tornase visível por um instante, mas há também uma sensação do mistério e da distância desse mundo. (FRYE, 1973 pp. 209 e 211)

\section{Referências}

BENJAMIN, Walter. Origem do drama barroco alemão (Tradução de Sergio Paulo Rouanet). São Paulo: Brasiliense, 1984.

BENTLEY, Eric. "A tragédia em trajes modernos". In O dramaturgo como pensador (Tradução de Ana Zelma Campos). Rio de Janeiro: Civilização Brasileira, 1991.

CAMUS, Albert. "Sur l'avenir de la tragédie". In: COUPRIE, Alain. Lire la tragédie. Paris: Dunod, 1994.

FRYE, Northop. “O mythos do outono: a tragédia”. In Anatomia da crítica (Tradução de Péricles Eugênio da Silva Ramos). São Paulo: Cultrix, 1973.

GASSNER, John. "Tragedy in the modern theatre". In: The theatre in our times: a survey of men, materials and movements in modern theatre. New York: Crown Publishers, 1960.

HOBSBAWM, Eric. A era dos extremos: o breve século XX - 1914-1991. São Paulo: Companhia das Letras, 1996.

KRUTCH, Joseph Wood. "The tragic fallacy". In LEVIN, Richard (Ed.). Tragedy: plays, theory, and criticism. New York: Harcourt, Brace \& World, 1960. 
MILLER, Arthur. "Tragedy and the common man". In: MARTIN, Robert A. and CENTOLA, Steven R. The theater essays of Arthur Miller. New York: Da Capo Press, 1996.

OLSON, Elder. "Modern drama and tragedy". In Tragedy and the theory of drama. Detroit: Wayne University Press, 1961.

STEINER, Georg. La muerte de la tragedia. Tradução E. L. Revol. Caracas: Monte Ávila Editores, 1991.

WILLIAMS, Raymond. Modern tragedy. London: Chatto \& Windus, 1966. 